\title{
Effect of Installation of Solar Collector on Performance of Balcony Split Type Solar Water Heaters
}

\author{
Xu Ji, Ming Li, Weidong Lin, Tufeng Zheng, and Yunfeng Wang \\ Key Laboratory of Advanced Technique and Preparation for Renewable Energy Materials, Ministry of Education, \\ School of Energy and Environmental Science, Yunnan Normal University, Kunming, Yunnan 650500, China
}

Correspondence should be addressed to Xu Ji; jixu@ynnu.edu.cn

Received 10 September 2015; Revised 27 November 2015; Accepted 20 December 2015

Academic Editor: Cheuk-Lam Ho

Copyright (C) $2015 \mathrm{Xu}$ Ji et al. This is an open access article distributed under the Creative Commons Attribution License, which permits unrestricted use, distribution, and reproduction in any medium, provided the original work is properly cited.

The influences of surface orientation and slope of solar collectors on solar radiation collection of balcony split type solar water heaters for six cities in China were analyzed by employing software TRNSYS. The surface azimuth had greater effect on solar radiation collection in high latitude regions. For deviation of the surface slope angle within $\pm 20^{\circ}$ around the optimized angle, the variation of the total annual collecting solar radiation was less than $5 \%$. However, with deviation of $70^{\circ}$ to $90^{\circ}$, the variation was up to $20 \%$. The effects of water cycle mode, reverse slope placement of solar collector, and water tank installation height on system efficiency were experimentally studied. The thermal efficiencies of solar water heater with single row horizontal arrangement allglass evacuated tubular collector were higher than those with vertical arrangement at the fixed surface slope angle of $90^{\circ}$. Compared with solar water heaters with flat-plate collector under natural circulation, the system thermal efficiency was raised up to $63 \%$ under forced circulation. For collector at reverse slope placement, the temperature-based water stratification in water tank deteriorated, and thus the thermal efficiency became low. For improving the system efficiency, an appropriate installation height of the water tank was suggested.

\section{Introduction}

With the challenges of fossil fuel depletion and global warming, utilization of renewable energy attracted extensive attention over the whole world. In the past twenty years, solar water heaters were widely used due to their low cost and simplicity in technology. The key component of solar water heater, the solar collector, gathers solar radiation and converts it into heat energy. The solar collector is usually installed on building's roof with a surface slope, which is equal to the local geographical latitude with an addition of 10 degrees. However, with development of urbanization, more and more high-rise building rose in the city. There is not enough room on buildings' roofs for all inhabitants to install their own solar water heaters. Moreover, when the hot water flows through the overlong pipes from heat water tanks on roofs to the users' rooms, the hot water would cool and even freeze in winter. So balcony split type solar water heater is proposed and plays a very important role in applications combined with high-rise buildings in recent years.
The collectors of balcony split type solar water heaters are usually attached on high-rise building external walls or balcony rails. The collectors do not always face south, the optimal orientation, but vary according to the building orientations. With consideration of light shadow to rooms and building beauty, it is difficult for collectors to be installed in optimal surface slope. The amount of heat collected by solar collectors relates closely with the collector surface slope. Many researches on the optimum orientation and tilt angle of solar collectors in some countries or regions, such as Brunei Darussalam, Syria, and Saudi Arabia, have been performed [1-4]. Gunerhan and Hepbasli [5] built a model to calculate the optimum tilt angles for which the total radiation on the collector surface was a maximum for a specific period and recommended that the solar collector was mounted at the monthly average tilt angle and the slope was adjusted once a month. Haitao and Yanfeng [6] analyzed the heat energy collected instantly by the evacuated tube solar collector with different slope angles in LHASA and considered the best angle in this area is $46^{\circ}$. Ong et al. [7] studied the performance 
of U-tube solar water heaters mounted on walls and balconies and concluded that their performance depended largely upon their orientation. For U-type evacuated glass tube solar collector fixed vertically on the balcony wall, the mean daily collector efficiency is about $40 \%$, and the solar fraction is satisfied in summer and autumn [8]. Besides, the influences of size and configuration of the water tank $[9,10]$, collectors with colour absorber [11-13], and fluid flow and heat transfer [1416 ] on the system performance were also studied. Hobbi and Siddiqui [17] modelled an indirect forced circulation solar water heating system with a flat-plate collector and optimized the design parameters by TRNSYS simulation program. The designed system could provide $83-97 \%$ and $30-62 \%$ of the hot water demands in summer and winter in Montreal of Canada, respectively. Seveda [18] performed some experiments on a natural circulation closed thermosyphon flat-plate solar water heater in sunny and cloudy days in India and improved the performance of the system by using glycol as working fluid. With the black ceramic coatings with solar absorptance of 0.93-0.97, the thermal efficiency of an allceramic solar collector is, respectively, $47.1 \%$ and $50 \%$ when the solar thermal collectors act as balcony railings and on building roofs [19]. Souliotis et al. [20] developed integrated collector storage (ICS) type solar water heaters. Chien et al. [21] developed a two-phase thermosyphon solar water heater with the best efficiency of $82 \%$ in experiments, higher than the conventional solar water heaters. Ong and Tiwari [2224] developed simulation methods and test performance of solar water heating systems under the thermosyphon mode between the collectors and the storage tank.

In this paper, the Transient System Simulation Program, TRNSYS $[25,26]$, was utilized to analyze the effects of surface orientation and surface slope of solar collectors on solar radiation collection in six typical cities of China with different geographic latitudes. TRNSYS, developed by the University of Wisconsin, is an effective tool for predicting the performance of solar water heaters. Afterwards, two sets of balcony split type solar water heaters with flat-plate collectors and two sets of balcony split type solar water heaters with all-glass evacuated tubular collectors were set up for experiments. The effects of the water cycle mode of the solar water heater, the reverse slope placement of the solar collector, and the installation height of the water tank on the efficiency of the solar heaters were studied.

\section{Effect of Surface Orientation and Slope on Solar Radiation Collection}

The TRNSYS Type 45 model is adopted to discuss the effects of azimuth angles and slope angles of solar collectors on solar radiation collection for the thermosyphon solar water heaters (TSWH). The required hourly meteorological data for all six cities were taken from the Typical Meteorological Year data bank. The simulation time step is set at 10 minutes.

\subsection{Effect of Surface Azimuth on Solar Radiation Collection.} Figure 1 shows the effects of surface azimuth of solar collectors on solar radiation collection in six cities of China with different geographic latitudes (geographic locations of
TABLE 1: Geographic location of six cities in China.

\begin{tabular}{lcc}
\hline \multirow{2}{*}{ City name } & \multicolumn{2}{c}{ Geographic location } \\
& East longitude & North latitude \\
\hline Qiqihar & 123.55 & 47.22 \\
Shanghai & 121.48 & 31.22 \\
Guangzhou & 113.23 & 23.16 \\
Beijing & 116.46 & 39.92 \\
Kunming & 102.70 & 25.07 \\
Haikou & 110.35 & 20.02 \\
\hline
\end{tabular}

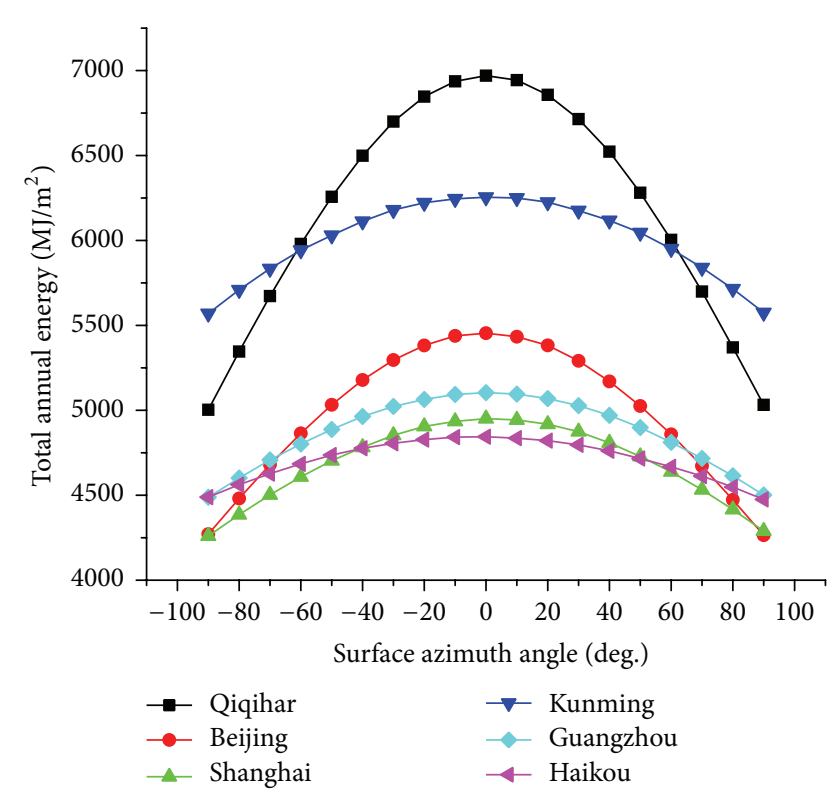

FIGURE 1: Effect of surface azimuth on collecting radiation in cities with different geographic locations.

the six cities are illustrated in Table 1 and Figure 2). Qiqihar and Beijing are located in higher northern latitude and have more significant change of the total annual solar energy with change of the azimuth, comparing with the other four cities. In Qiqihar, the total annual solar energy is $7000 \mathrm{MJ} / \mathrm{m}^{2}$ and $5000 \mathrm{MJ} / \mathrm{m}^{2}$, respectively, when the solar collector faces the south and has the azimuth of $90^{\circ}$. The variety is up to $2000 \mathrm{MJ} / \mathrm{m}^{2}$. In Beijing, the total annual solar energy is $5300 \mathrm{MJ} / \mathrm{m}^{2}$ and $4200 \mathrm{MJ} / \mathrm{m}^{2}$, respectively, when the solar collector faces the south and has the azimuth of $90^{\circ}$. The variety is $1100 \mathrm{MJ} / \mathrm{m}^{2}$. Haikou is with the lowest northern latitude, and the curve of surface azimuth's effect on solar radiation collection for Haikou is the most flat. The total annual solar energy is $4800 \mathrm{MJ} / \mathrm{m}^{2}$ and $4500 \mathrm{MJ} / \mathrm{m}^{2}$, respectively, when the solar collector faces the south and has the azimuth of $90^{\circ}$. The variety is only $300 \mathrm{MJ} / \mathrm{m}^{2}$. This means that the solar radiation collection is affected by the surface azimuth of the solar collector. The higher the latitude of the place is, the greater the effect of the surface azimuth of the solar collector on solar radiation collection is.

Figure 3 shows the effects of surface azimuth of solar collectors with $25^{\circ}$ slope angle on the total annual solar 


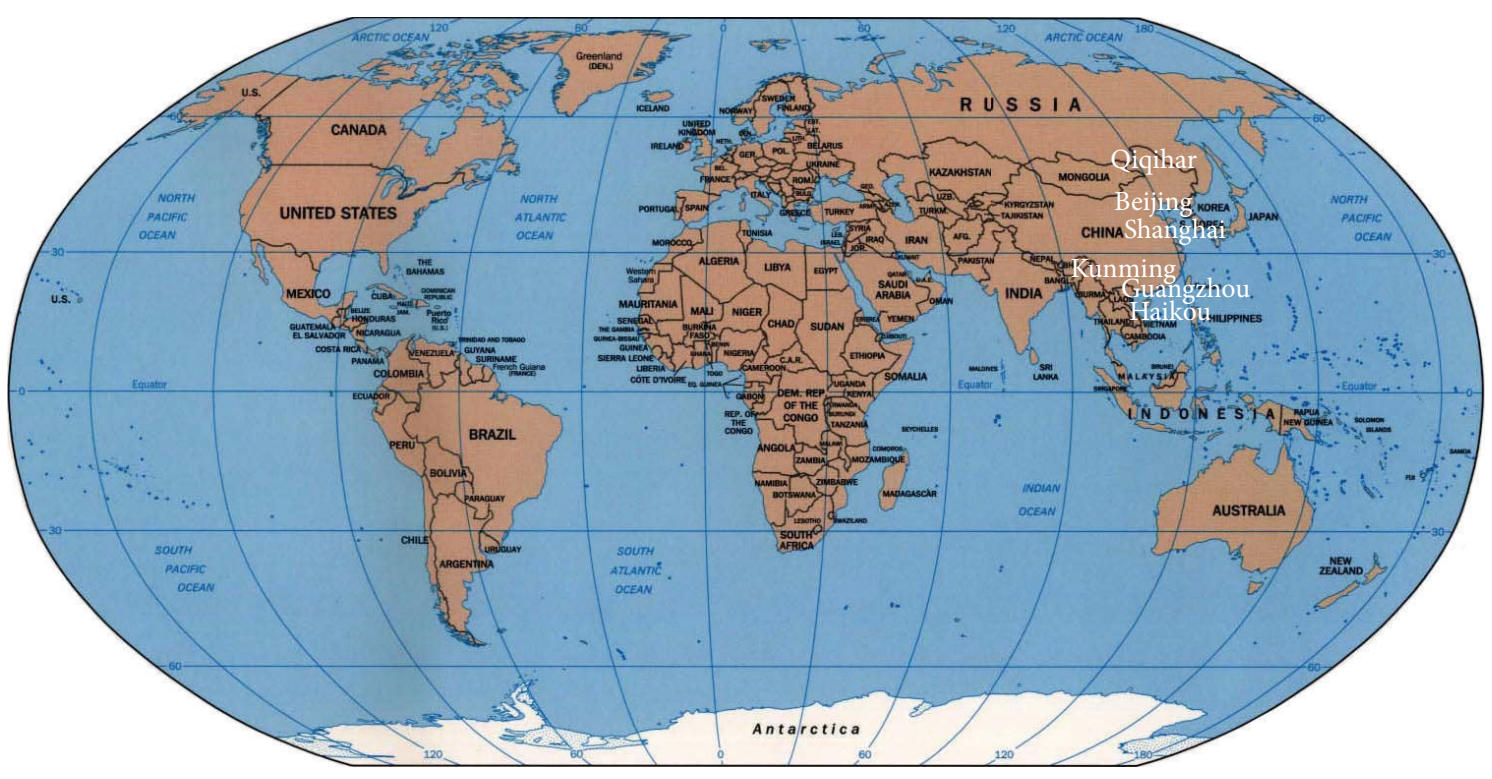

Figure 2: Location of six cities in China.

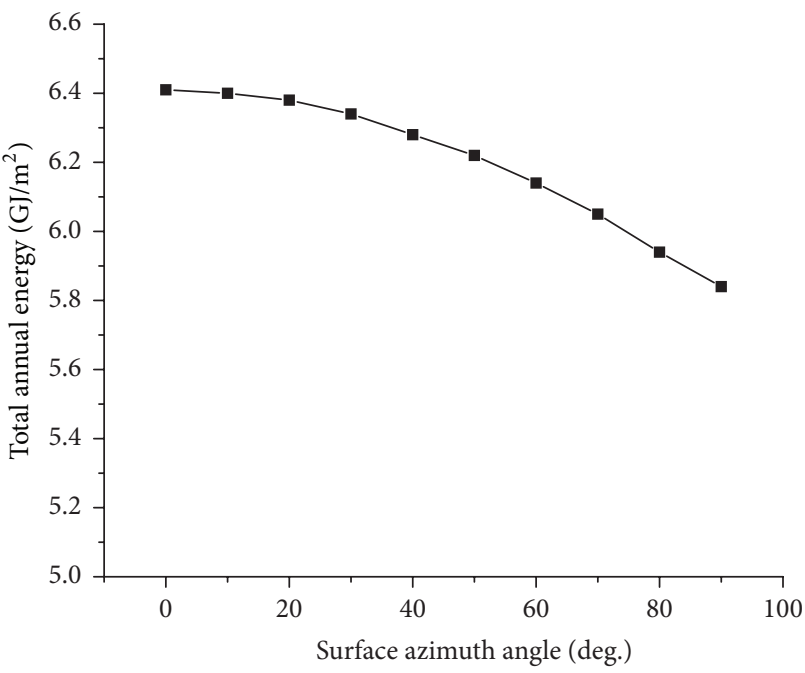

FIGURE 3: Effect of surface azimuth on solar radiation collection in Kunming.

radiation collection in Kunming, China. In Figure 3, the most total annual solar radiation collection is obtained with surface azimuth of $0^{\circ}$. The total annual solar radiation collection decreases with increase of the surface azimuth angle. When the surface azimuth angle changes from $0^{\circ}$ to $20^{\circ}$, the variation of the total annual collecting solar radiation is less than $1 \%$. However, with further increasing of the surface azimuth, the variance on the total annual collecting solar radiation becomes larger. When the surface azimuth increases from $40^{\circ}$ to $60^{\circ}$, the change of the collecting solar radiation is around $2.3 \%$. And the change is $3.3 \%$ when the surface azimuth varies from $70^{\circ}$ to $90^{\circ}$. The total annual collecting solar radiation at the surface azimuth of $90^{\circ}$ is $91.0 \%$ of that at the surface

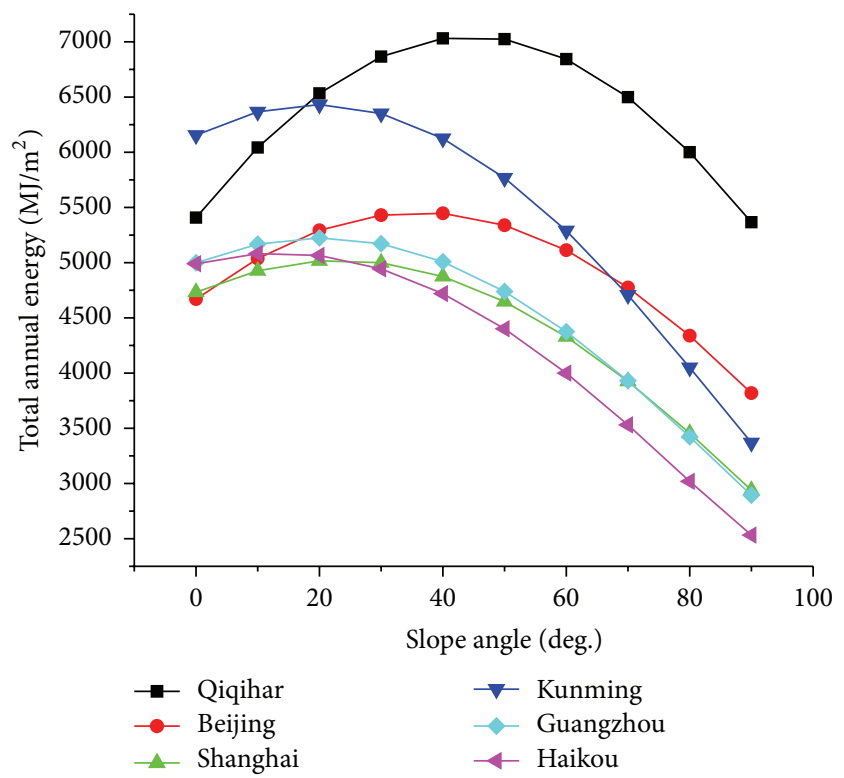

FIGURE 4: Effect of surface slope on annual solar radiation collection in cities with different geographic locations.

azimuth of $0^{\circ}$. Therefore, the surface azimuth has little effect on the collecting solar radiation in Kunming, especially when the surface azimuth is within $20^{\circ}$ from the south orientation.

\subsection{Effect of Surface Slope on Solar Radiation Collection.} Figure 4 shows the effects of the surface slope of the solar collectors on annual solar radiation collection in six cities of China with different geographic locations. In the figure, the optimized surface slope angle is about the local geographic latitude minus $10^{\circ}$ when the solar collector faces south. With 


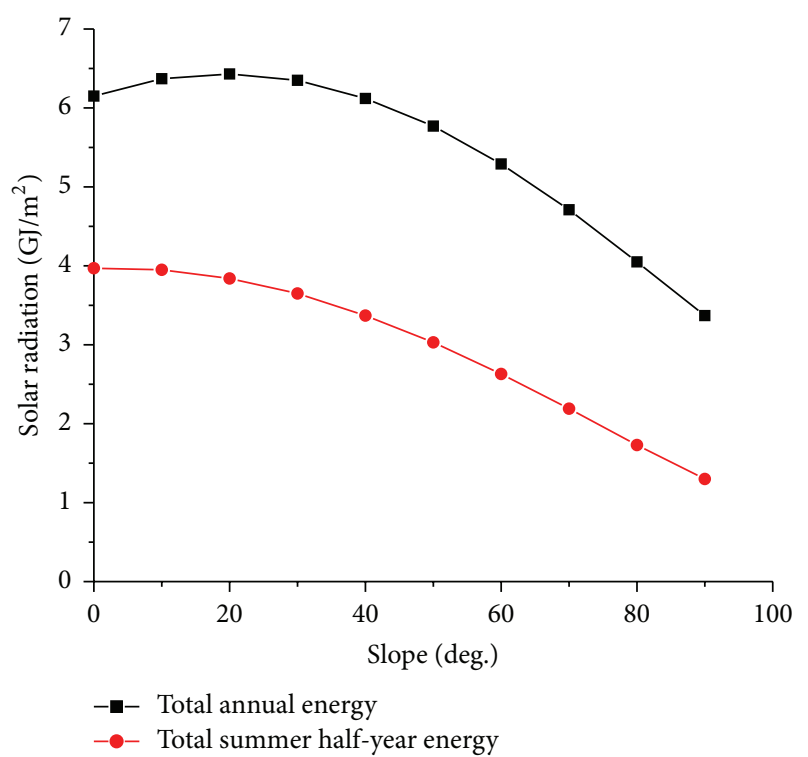

FIGURE 5: Effect of surface slope on solar radiation collection in Kunming.

a change of the surface slope angle within $\pm 20^{\circ}$ around the optimized surface slope angle, the variation of the total annual collecting solar radiation is less than $5 \%$. However, with further increasing or decreasing of the surface slope angle around the optimized surface slope angle, the variety of the total annual collecting solar radiation becomes larger. With the deviation of the surface slope angle from the optimized surface slope angle from $20^{\circ}$ to $40^{\circ}$, the change of the total annual collecting solar radiation is around $5 \%$. With the deviation of the surface slope angle from the optimized surface slope angle from $70^{\circ}$ to $90^{\circ}$, the change of the total annual collecting solar radiation is up to more than $20 \%$. Therefore, the vertical installation of the solar collector is not proper from the view of solar radiation collection. With the comprehensive consideration of solar radiation collection, external wall load-bearing, light shadow to the lower rooms, and building beauty, the surface slope angle of $60^{\circ}$ is appropriate.

In Figure 5, the optimal surface slope angle of the solar collector is $18^{\circ}$ in Kunming when the collector surface faces south, and in this case, the most total annual collecting solar radiation of $6.43 \mathrm{GJ} / \mathrm{m}^{2}$ is achieved. The variation of the collecting solar radiation is less than $5 \%$ with a change of the surface slope angle from the optimal angle within $20^{\circ}$. However, with a further increase/decrease of the surface slope angle, the influence of the surface slope angle on the total annual collecting solar radiation becomes significant. When the surface slope angle increases from $70^{\circ}$ to $90^{\circ}$, the change of the collecting solar radiation is more than $20 \%$. The total annual collecting solar radiation is $3.37 \mathrm{GJ} / \mathrm{m}^{2}$ when the surface slope angle is $90^{\circ}$ and is only $52.4 \%$ of the most total annual collecting solar radiation at the optimal surface slope angle.

The total collecting solar radiation of $3.97 \mathrm{GJ} / \mathrm{m}^{2}$ in summer half year (from March 21 to September 23) is achieved in
Kunming when the surface slope angle of the solar collector is $0^{\circ}$. The total collecting solar radiation in summer half year is around $1.3 \mathrm{GJ} / \mathrm{m}^{2}$ with the surface slope angle of $90^{\circ}$ and is $32.7 \%$ of that at the surface slope angle of $0^{\circ}$. The total collecting solar radiation in summer half year is around $1.4 \mathrm{GJ} / \mathrm{m}^{2}$ with the surface slope angle of $70^{\circ}$ and is $55.1 \%$ of that at the surface slope angle of $0^{\circ}$. It was shown that, for balcony split type solar water heaters, the vertical installation of the solar collector would result in relatively little solar radiation collection. With comprehensive consideration of the solar radiation collection, the wall load-bearing, and the avoidance of light shadow to the rooms, the installation of the solar collectors with a slope angle of $70^{\circ}$ is optimal. The above simulation results were in good agreement with some conclusions drawn by [27-29].

\section{Experimental Setup}

Two sets of balcony split type solar water heaters with flatplate collectors and two sets of balcony split type solar water heaters with all-glass evacuated tubular collectors were set up for experiments. The tilt angle of the collector bracket is adjustable and varies from 0 to 90 . The total area of the flatplate collector in each set of balcony split type solar water heaters is $1.5 \mathrm{~m}^{2}$, and the effective radiation collection area is $1.325 \mathrm{~m}^{2}$. The frames of the flat-plate collectors are made from stainless steel plate, the thermal insulating material is rock wool with the thickness of $4 \mathrm{~cm}$, and the cover plate is made from toughened glass with optical transmittance of $90 \%$. The aperture area (the effective radiation collection area) of the all-glass evacuated tubular collector in each set of balcony split type solar water heaters is $1.317 \mathrm{~m}^{2} .10$ evacuated collector tubes are placed side by side in each collector. The length of a single tube is $1800 \mathrm{~mm}$, the outer glass tube diameter is $58 \mathrm{~mm}$, and the inner glass tube diameter is $47 \mathrm{~mm}$. The aluminum pipe, wrapped with the rubber insulation cotton, is employed to build the circulating pipeline. The cylindrical water tank, with a total volume of $120 \mathrm{~L}$, is horizontally placed. Other parameters of the system are shown in Table 2.

The thermal performance testing system of solar water heaters TRM-2, made by Jinzhou Sunlight Technology Development Company Ltd., was employed in our experiments. The technical specifications of the test equipment are shown in Table 3. The experiments were performed in Kunming, China, with the geographic coordinate $\left(25.02^{\circ} \mathrm{N}, 102.68^{\circ} \mathrm{E}\right)$ from January to May. The system automatic recording time step was set in 10 minutes in the experiments.

\section{Results and Discussions}

4.1. Performance of Solar Water Heater with All-Glass Evacuated Tubular Collector at a Fixed Surface Slope Angle of $90^{\circ}$ under the Natural Circulation. The thermal performance of the solar collector is one of the most important factors to decide the performance of solar water heater. The HottelWhillier equation is usually used for evaluating the thermal performance of the solar energy heat-collection plates:

$$
Q_{u}=A_{c} F_{R}\left(G_{T}(\tau \alpha)-U_{L}\left(T_{i}-T_{a}\right)\right) \text {, }
$$


TABLE 2: Parameters of the solar water heaters.

\begin{tabular}{|c|c|c|}
\hline \multirow[b]{2}{*}{ Items } & \multicolumn{2}{|c|}{ Parameters } \\
\hline & $\begin{array}{l}\text { Solar water heater with flat-plate } \\
\text { collector }\end{array}$ & $\begin{array}{c}\text { Solar water heater with all-glass } \\
\text { evacuated tubular collector }\end{array}$ \\
\hline Aperture area of the collector $\left(\mathrm{m}^{2}\right)$ & 1.325 & 1.317 \\
\hline$F_{R}(\tau \alpha)$ & 0.76 & \\
\hline$F_{R} U_{L}\left(\mathrm{~kJ} / \mathrm{hr} \cdot \mathrm{m}^{2} \cdot \mathrm{K}\right)$ & 15 & \\
\hline Assemble angle of collector (degrees) & $0 \sim 90$ & $0 \sim 90$ \\
\hline Distance between water inlet and water outlet of collector $(\mathrm{m})$ & 0.86 & \\
\hline Distance between water outlet of collector and tank bottom ( $\mathrm{m})$ & $0.14 \sim 1.34$ & \\
\hline Length of cycle pipeline $(\mathrm{m})$ & $2 \sim 4.5$ & $2 \sim 4.5$ \\
\hline Heat loss coefficient of cycle pipeline $\left(\mathrm{kJ} / \mathrm{hr} \cdot \mathrm{m}^{2} \cdot \mathrm{K}\right)$ & 0.1 & 0.1 \\
\hline Tank volume $\left(\mathrm{m}^{3}\right)$ & 0.12 & 0.12 \\
\hline Total heat loss coefficient $(\mathrm{kJ} / \mathrm{hr} \cdot \mathrm{K})$ & 5.0 & \\
\hline
\end{tabular}

TABLE 3: Technical index of TRM-2 thermal performance testing system of solar water heaters.

\begin{tabular}{lcccc}
\hline & Measurement range & Measurement accuracy & Resolution & Other parameters \\
\hline Temperature & $-40^{\circ} \mathrm{C} \sim 350^{\circ} \mathrm{C}$ & $\pm 0.1^{\circ} \mathrm{C}$ & $0.1^{\circ} \mathrm{C}$ & \\
Ambient temperature & $-40^{\circ} \mathrm{C} \sim 70^{\circ} \mathrm{C}$ & $\pm 0.1^{\circ} \mathrm{C}$ & $0.1^{\circ} \mathrm{C}$ & \\
Wind speed & $0 \sim 60 \mathrm{~m} / \mathrm{s}$ & $\pm(0.3+0.03) \mathrm{m} / \mathrm{s}$ & $0.1 \mathrm{~m} / \mathrm{s}$ & Threshold wind velocity $\geq 0.5 \mathrm{~m} / \mathrm{s}$ \\
Solar radiation & $0 \sim 2000 \mathrm{~W} / \mathrm{m}^{2}$ & $\pm 5 \% \mathrm{~W} / \mathrm{m}^{2}$ & $1 \mathrm{~W} / \mathrm{m}^{2}$ & \\
\hline
\end{tabular}

where $Q_{u}$ is the useful gain of the solar energy heat-collection plate, $\mathrm{W} / \mathrm{m}^{2} ; A_{c}$ is the heat-collection area of the solar energy heat-collection plate; $F_{R}$ is the thermal conversion factor of the heat-collection plate; $G_{T}$ is the solar radiation on the tilted surface; $\tau$ is the transmissivity of the glass covering; $\alpha$ is the absorptivity of the collector plate; $U_{L}$ is the thermal transmittance from collector surface to ambient air; $T_{i}$ is the collector surface temperature; $T_{a}$ is the ambient air temperature.

The heat-collection efficiency of the heat-collection plate is defined as the ratio of the useful gain to the solar radiation on the solar energy heat-collection plate:

$$
\eta=\frac{Q_{u}}{A_{c} G_{T}}
$$

where $\eta$ is the heat-collection efficiency of the heat-collection plate, $\%$.

According to the arrangement mode of the evacuated tubes in the solar collector, the evacuated tubular collector can be classified as the single row vertical arrangement collector, the single row horizontal arrangement collector, and the double row horizontal arrangement collector. Some experiments were performed in winter (January) in Kunming by utilizing the balcony wall-mounted solar water heater with the single row horizontal arrangement collector and the single row vertical arrangement collector at a fixed surface slope angle of $90^{\circ}$ to investigate their performances under the natural circulation. The experimental results are shown in Table 4.

In Table 4, the system thermal efficiencies of the solar water heater with the single row horizontal arrangement all-glass evacuated tubular collector were higher than those with the single row vertical arrangement all-glass evacuated tubular collector at the fixed surface slope angle of $90^{\circ}$. With the initial water temperature around $13^{\circ} \mathrm{C}$ and the solar radiance around $16.5 \mathrm{MJ}$, the final water temperatures of the former reached around $40^{\circ} \mathrm{C}$ after 6 hours, the water temperature rise was $24.6-28.2^{\circ} \mathrm{C}$, and the system thermal efficiencies were around $60 \%$. However, with similar initial water temperature and similar solar radiance, the final water temperatures of the latter were only around $35^{\circ} \mathrm{C}$ after 6 hours, the water temperature rise was $19.8-22.1^{\circ} \mathrm{C}$, and the system thermal efficiencies were below $49 \%$. The main reason is, for the solar water heater with the single row vertical arrangement all-glass evacuated tubular collector, the cold fluid flows down to the bottom of the evacuated tube along the shaded side of the evacuated tube. In the process of flowing down, the cold fluid absorbs energy unceasingly and merges into the upwelling current before it reaches the bottom of the tube. That is to say, there is the short circuit of the fluid circulation, which results in the heat transportation deterioration of the system and reduces the system efficiency. In this work, the length of the all-glass evacuated tube is $1800 \mathrm{~mm}$. To reduce the tubular length would be helpful for enhancing the heat transportation of the system and improving the efficiency.

4.2. Performance of Solar Water Heater with Flat-Plate Collector at a Fixed Surface Slope Angle of $90^{\circ}$ under Natural Circulation and Forced Circulation. The size of the flat-plate collector is usually $2 \mathrm{~m} \times 1 \mathrm{~m}$ or $1.5 \mathrm{~m} \times 1 \mathrm{~m}$, and its height is $2 \mathrm{~m}$ or $1.5 \mathrm{~m}$. However, the height of balcony sidewall is 
TABLE 4: Performance of all-glass evacuated tubular collector at a surface slope angle of $90^{\circ}$.

\begin{tabular}{|c|c|c|c|c|c|c|c|c|}
\hline \multirow{2}{*}{ Date } & \multicolumn{5}{|c|}{ Single row horizontal arrangement } & \multicolumn{3}{|c|}{ Single row vertical arrangement } \\
\hline & Jan. 24 & Jan. 25 & Jan. 28 & Jan. 29 & Jan. 30 & Jan. 23 & Jan. 24 & Jan. 25 \\
\hline Ambient temperature $\left({ }^{\circ} \mathrm{C}\right)$ & 21.7 & 16.6 & 14.6 & 14.7 & 15.6 & 16.3 & 17.2 & 16.6 \\
\hline Average wind speed $(\mathrm{m} / \mathrm{s})$ & 0.5 & 0.7 & 1.3 & 1.6 & 0.7 & 1.4 & 0.6 & 0.7 \\
\hline Irradiance $(\mathrm{MJ})$ & 17.7 & 15.8 & 17.2 & 16.4 & 17.1 & 17.0 & 17.4 & 15.8 \\
\hline Time (hr) & 6.0 & 6.0 & 6.0 & 6.0 & 6.0 & 6.0 & 6.0 & 6.0 \\
\hline Initial temperature of $\operatorname{tank}\left({ }^{\circ} \mathrm{C}\right)$ & 14.4 & 12.7 & 12.7 & 13.1 & 13.6 & 15.2 & 13.8 & 14.2 \\
\hline Final temperature of tank $\left({ }^{\circ} \mathrm{C}\right)$ & 40.7 & 37.3 & 39.7 & 39.6 & 41.8 & 36.4 & 35.9 & 34.0 \\
\hline Temperature rise $\left({ }^{\circ} \mathrm{C}\right)$ & 26.3 & 24.6 & 27.0 & 26.5 & 28.2 & 21.2 & 22.1 & 19.8 \\
\hline Tank volume (L) & 120 & 120 & 120 & 120 & 120 & 120 & 120 & 120 \\
\hline Efficiency & 0.565 & 0.595 & 0.600 & 0.617 & 0.629 & 0.475 & 0.483 & 0.480 \\
\hline
\end{tabular}

TABLE 5: Performance of solar water heater with flat-plate collector at a fixed surface slope angle of $90^{\circ}$ under natural circulation and forced circulation.

\begin{tabular}{|c|c|c|c|c|}
\hline \multirow{2}{*}{ Date } & \multicolumn{2}{|c|}{ Natural circulation } & \multicolumn{2}{|c|}{ Forced circulation } \\
\hline & Jan. 24 & Jan. 25 & Feb. 3 & Feb. 4 \\
\hline Ambient average temperature $\left({ }^{\circ} \mathrm{C}\right)$ & 17.3 & 16.6 & 17.4 & 16.6 \\
\hline Average wind speed (m/s) & 0.6 & 0.7 & 1.1 & 1.4 \\
\hline Irradiance $(\mathrm{MJ})$ & 17.6 & 15.8 & 15.7 & 15.3 \\
\hline Time (hr) & 6.0 & 6.0 & 6.0 & 6.0 \\
\hline Initial temperature of $\operatorname{tank}\left({ }^{\circ} \mathrm{C}\right)$ & 14.3 & 13.8 & 16.2 & 19.6 \\
\hline Final temperature of $\operatorname{tank}\left({ }^{\circ} \mathrm{C}\right)$ & 24.4 & 22.9 & 42.3 & 44.8 \\
\hline Temperature rise $\left({ }^{\circ} \mathrm{C}\right)$ & 10.1 & 9.1 & 26.1 & 25.2 \\
\hline Efficiency & 0.218 & 0.219 & 0.629 & 0.654 \\
\hline Useful energy (MJ) & 5.08 & 4.56 & 13.12 & 12.64 \\
\hline Consumption of energy (MJ) & 0.0 & 0.0 & 1.73 & 1.73 \\
\hline
\end{tabular}

generally around $1 \mathrm{~m}$. It is not feasible to mount directly the flat-plate collector on the balcony sidewall according to the conventional installation method. An alternative solution is to put the collector on its side, so its height would meet the requirement of the balcony sidewall.

But placing the collector on its side is not conducive to the natural circulation of the system and would ultimately affect the thermal efficiency of the system. Therefore, the forced circulation is necessary in some cases. Table 5 presents the experimental results of the solar water heater with the flatplate collector at a fixed surface slope angle of $90^{\circ}$ under natural circulation and forced circulation. The pump power for the forced circulation is $80 \mathrm{~W}$, and the mass flow rate is $40 \mathrm{~kg} / \mathrm{h}$.

In Table 5, the efficiency of the solar water heater with the flat-plate collector placed on its side at a fixed surface slope angle of $90^{\circ}$ under natural circulation is only $21.8 \%$. Compared with the efficiency of the solar water heater with the single row all-glass evacuated tubular collector at a fixed surface slope angle of $90^{\circ}$ under the natural circulation in Table 4, the efficiency of the solar water heater with the flat-plate collectors is disappointing under the same conditions. It mainly results from the small diameter of the up-flow tube in the flat-plate collector; consequently, the flow resistance is large, and the system circulation is not smooth. The utilization of the forced circulation may improve the circulation of the system. In similar irradiance and wind speed, the system thermal efficiency could be raised up to $63 \%$, and the circulating pump power is only $13 \%$ of the heat gain.

4.3. Effect of Reverse Slope Placement of Evacuated Tubular Collector on Performance of Solar Water Heater under Natural Circulation. The driving force of the water circulation of the solar water heater under natural circulation originates from the thermosyphon pressure and is relatively smaller than that under water forced circulation. In designed installation, the water outlet of the collector is generally slightly higher than the water inlet, at least at the same horizontal level, to reduce resistance and increase thermosyphon pressure. That is to say, the collecting tube is placed in the form of climbing toward the water outlet. The structural characteristics of the flat-plate solar water heater usually ensure the down slope setup of the solar collector. For the all-glass evacuated tubular collector of split type solar water heater, the water outlet of the collector could be lower than the water inlet due to the uneven floor or an installation error in an actual installation process. In the circumstances, the water circulation direction 
TABLE 6: Experimental performances of all-glass vacuum tube solar water heaters with collectors at down slope placement and at reverse slope placement.

\begin{tabular}{|c|c|c|c|c|c|}
\hline \multirow{2}{*}{ Date } & \multicolumn{3}{|c|}{ Reverse slope placement } & \multicolumn{2}{|c|}{ Down slope placement } \\
\hline & Feb. 3 & Feb. 4 & March 1 & Jan. 29 & Jan. 30 \\
\hline Ambient average temperature $\left({ }^{\circ} \mathrm{C}\right)$ & 17.1 & 16.8 & 20.3 & 14.8 & 15.6 \\
\hline Average wind speed (m/s) & 1.2 & 1.4 & 0.3 & 1.6 & 0.7 \\
\hline Irradiance $(\mathrm{MJ})$ & 20.2 & 20.6 & 19.2 & 19.7 & 20.6 \\
\hline Time (hr) & 6.0 & 6.0 & 6.0 & 6.0 & 6.0 \\
\hline Initial temperature of $\operatorname{tank}\left({ }^{\circ} \mathrm{C}\right)$ & 27.7 & 14.3 & 16.9 & 12.0 & 19.6 \\
\hline Final temperature of $\operatorname{tank}\left({ }^{\circ} \mathrm{C}\right)$ & 49.9 & 38.7 & 40.7 & 45.2 & 43.6 \\
\hline Tank volume (L) & 120 & 120 & 120 & 120 & 120 \\
\hline Temperature rise $\left({ }^{\circ} \mathrm{C}\right)$ & 22.2 & 24.5 & 23.8 & 33.2 & 24.0 \\
\hline Efficiency & 0.419 & 0.453 & 0.471 & 0.641 & 0.617 \\
\hline
\end{tabular}

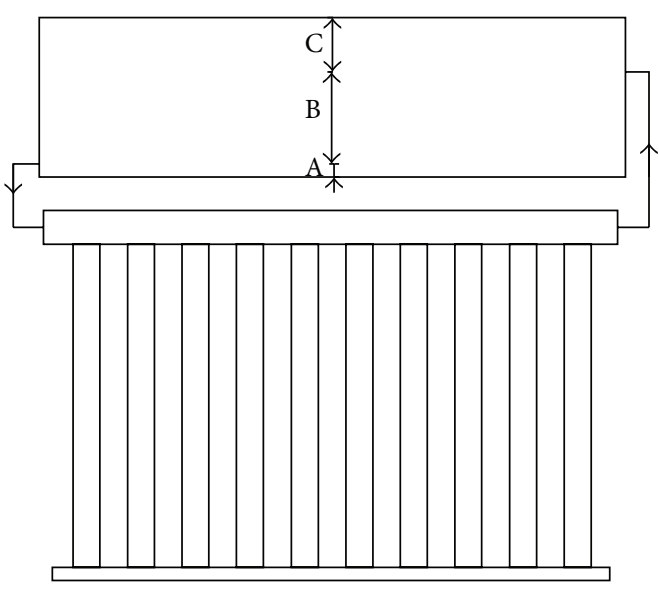

(a)

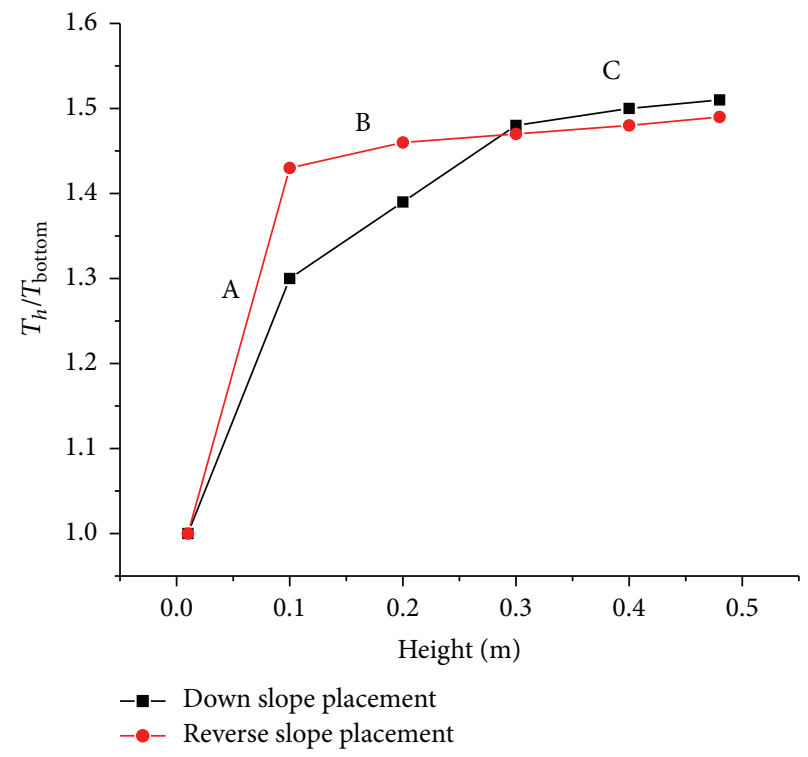

(b)

Figure 6: Temperature-based water stratification in water tank for collectors at down slope placement and at reverse slope placement.

of the natural circulation solar water heater would change, which consequently affects the mixing way of the cold water and the hot water and the water stratification in water tank. The performance of the solar water heater is degraded.

Table 6 shows the experimental performances of all-glass vacuum tubular solar water heaters with collectors at down slope placement and at $5^{\circ}$ angle reverse slope placement. In similar solar irradiance, ambient temperature, and wind speed, the collecting efficiency of solar water heaters with collector at down slope placement is above $60 \%$; however, the collecting efficiency of solar water heaters with collector at reverse slope placement is about $45 \%, 15 \%$ lower than that of the former.

The performance deterioration of the solar water heater with collector at reverse slope placement results from the change of the temperature-based water stratification in water tank. In Figure 6(a), the water tank is divided into three regions from the bottom to the top of the tank: region $\mathrm{A}$, region $\mathrm{B}$, and region $\mathrm{C}$. Region $\mathrm{A}$ is from the tank bottom to the water outlet of the tank. With the region, the deposition on the tank bottom could be avoided to enter the collector. The water in region A does not circulate into the collector, and it is actually a stagnant water area. Region B is from the water outlet to the water inlet of the tank. Region $\mathrm{C}$ is from the water inlet to the tank top.

In Figure 6(b), $T_{h} / T_{\text {bottom }}$ rises linearly in region $\mathrm{A}$ for collector at both the down slope placement and the reverse slope placement. The water temperature distribution in the water stagnant area is due to the heat transfer method: heat conduction only. The heat input in the region originates from the water in region $\mathrm{B}$. In region $\mathrm{B}$, the water temperature has a linear rise with the increase of the height when the collector is at down slope placement. In this case, the water circulation direction is as shown in Figure 6(a), and the hot water from 
the collector enters the water tank from the inlet on the upper part. The higher temperature water is on the upper part and the lower temperature water is on the lower part, which would not result in the flow of the water in the region. So the temperature-based water stratification forms. The water outlet for users is on the upper part of the tank; therefore, with the down slope placement, the hot water is preferentially supplied to users. However, for collector at reverse slope placement, the water temperature varies slightly in region $\mathrm{B}$, and the water stratification is worse than the former. In this case, the water circulation direction is reverse with that shown in Figure 6(a) and the hot water from the collector enters the water tank from the inlet on the lower part. The higher temperature water is on the lower part and the lower temperature water is on the upper part, which would result in the water mix in the region. The temperature-based water stratification is not clear. In region $\mathrm{C}$, the buoyancy results in the rise of hot water and the water mix, so the water temperature varies gently for collector at both the down slope placement and the reverse slope placement. From the above analysis, for collector at the reverse slope placement, the temperature-based water stratification in water tank is poor, and the collection efficiency is low. The solar collector should avoid reverse slope placement.

4.4. Effect of Installation Height of the Water Tank on Efficiency of the Solar Heater. For balcony split type solar water heater, the height difference between the water tank and the solar collector is the driving force of the natural water circulation. Too small height difference would result in shortage of the circulation driving force. On the contrary, too large height difference would increase the length of the pipeline and the cooling area, thus lowering the thermal efficiency of the water heater. Therefore, the modest height difference is essential to achieve enough circulation pressure and simultaneously keep the high thermal efficiency of the water heaters as much as possible and improve water temperature stratification in the water tank. Figure 7 shows the effects of the height of the water tank on the efficiency of the solar heater.

In Figure 7, when the height difference between the bottom of the water tank and the outlet of the collector varied from $0.14 \mathrm{~m}$ to $0.74 \mathrm{~m}$, the thermal efficiency of the solar water heater increased from $62.5 \%$ to $67.7 \%$. The rise mainly resulted from the increment of the thermal siphon pressure greater than the increment of the resistance of ducting in the stage. The boost of the water circulation would timely bring the heat collected by the solar collector to the water tank, thereby increasing the system thermal efficiency. However, with a further increase of the height difference from $0.74 \mathrm{~m}$ to $1.34 \mathrm{~m}$, the thermal efficiency reduced from $67.7 \%$ to $64 \%$. In this stage, while the rise of the installation height of the water tank would magnify the thermal siphon pressure, it also increases greatly the resistance of ducting and the cooling area of the system, eventually leading to the fall of the system thermal efficiency instead of the rise. That is to say, there is an optimal height difference between the bottom of the water tank and the outlet of the collector for the thermal efficiency of the system to reach its maximum. For the solar water heater with a total solar collecting area of $1.5 \mathrm{~m}^{2}$ and

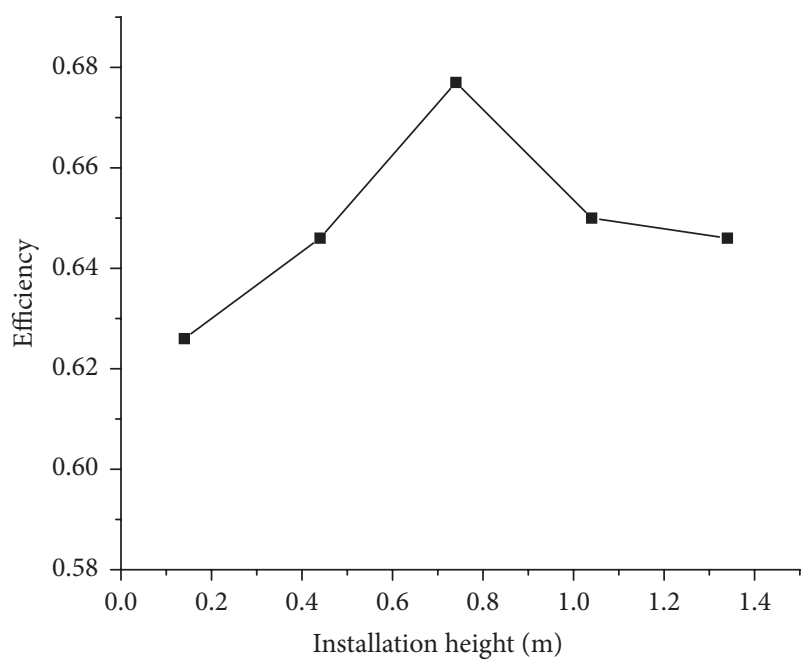

FIGURE 7: Effect of the height of the water tank on the efficiency of the solar heater.

a water tank capacity of $120 \mathrm{~L}$ (as discussed in the work), the optimal height difference is around $0.74 \mathrm{~m}$. In the actual installation, the height difference of $0.44 \mathrm{~m} \sim 1.04 \mathrm{~m}$ according to particular case is considered as reasonable, because the change of the system thermal efficiency in this range does not exceed $3 \%$.

\section{Conclusions}

TRNSYS was employed to analyze the effect of surface orientation and slope of solar collectors on solar radiation collection of balcony split type solar water heaters. In regions with high latitude, the surface azimuth of solar collector had greater effect on solar radiation collection. For deviation of surface slope angle within $\pm 20^{\circ}$ around the optimized angle, the variation of the total annual collecting solar radiation was less than $5 \%$. However, with deviation of $70^{\circ}$ to $90^{\circ}$, the variation was up to $20 \%$.

In our experiments, the system thermal efficiency of solar water heater with single row horizontal arrangement allglass evacuated tubular collector was higher than those with single row vertical arrangement at the fixed surface slope angle of $90^{\circ}$. Under forced circulation, the system thermal efficiency of solar flat-plate water heater was raised up to $63 \%$ compared with that under natural circulation, and the circulating pump power was only $13 \%$ of the heat gain. For collector at reverse slope placement, the temperature-based water stratification in water tank deteriorated, and thus the thermal efficiency became low. The height difference between water tank and solar collector had influence on the thermal siphon pressure and the resistance. For improving the system efficiency, an appropriate installation height of the water tank was suggested.

\section{Conflict of Interests}

The authors declare that there is no conflict of interests regarding the publication of this paper. 


\section{Acknowledgment}

This work is partial fulfillment of funded research programs 51106134, financially supported by the National Natural Science Foundation of China.

\section{References}

[1] S. Bari, "Optimum orientation of domestic solar water heaters for the low latitude countries," Energy Conversion and Management, vol. 42, no. 10, pp. 1205-1214, 2001.

[2] M. A. B. H. M. Yakup and A. Q. Malik, "Optimum tilt angle and orientation for solar collector in Brunei Darussalam," Renewable Energy, vol. 24, no. 2, pp. 223-234, 2001.

[3] K. Skeiker, "Optimum tilt angle and orientation for solar collectors in Syria," Energy Conversion \& Management, vol. 50, no. 9, pp. 2439-2448, 2009.

[4] A. A. El-Sebaii, F. S. Al-Hazmi, A. A. Al-Ghamdi, and S. J. Yaghmour, "Global, direct and diffuse solar radiation on horizontal and tilted surfaces in Jeddah, Saudi Arabia," Applied Energy, vol. 87, no. 2, pp. 568-576, 2010.

[5] H. Gunerhan and A. Hepbasli, "Determination of the optimum tilt angle of solar collectors for building applications," Building and Environment, vol. 42, no. 2, pp. 779-783, 2007.

[6] W. Haitao and L. Yanfeng, "Best angle of tandem solar collector in LHASA," Energy Conservation Technology, vol. 27, no. 6, pp. 525-526, 2009.

[7] K.-S. Ong, W.-L. Tong, and C. David, "Performance of U-tube solar water heaters facing different directions," Journal of Energy and Power Engineering, vol. 7, pp. 1729-1734, 2013.

[8] R. Li, Y. Dai, and R. Wang, "Experimental investigation and simulation analysis of the thermal performance of a balcony wall integrated solar water heating unit," Renewable Energy, vol. 75, pp. 115-122, 2015.

[9] A. M. Shariah and G. O. G. Löf, "The optimization of tankvolume-to-collector-area ratio for a thermosyphon solar water heater," Renewable Energy, vol. 7, no. 3, pp. 289-300, 1996.

[10] A. Hasan, "Thermosyphon solar water heaters: effect of storage tank volume and configuration on efficiency," Energy Conversion and Management, vol. 38, no. 9, pp. 847-854, 1997.

[11] T. N. Anderson, M. Duke, and J. K. Carson, "The effect of colour on the thermal performance of building integrated solar collectors," Solar Energy Materials and Solar Cells, vol. 94, no. 2, pp. 350-354, 2010.

[12] S. Kalogirou, Y. Tripanagnostopoulos, and M. Souliotis, "Performance of solar systems employing collectors with colored absorber," Energy and Buildings, vol. 37, no. 8, pp. 824-835, 2005.

[13] A. Schüler, C. Roecker, J.-L. Scartezzini et al., "On the feasibility of colored glazed thermal solar collectors based on thin film interference filters," Solar Energy Materials and Solar Cells, vol. 84, no. 1-4, pp. 241-254, 2004.

[14] R. Cònsul, I. Rodríguez, C. D. Pérez-Segarra, and M. Soria, "Virtual prototyping of storage tanks by means of threedimensional CFD and heat transfer numerical simulations," Solar Energy, vol. 77, no. 2, pp. 179-191, 2004.

[15] G. L. Morrison, I. Budihardjo, and M. Behnia, "Measurement and simulation of flow rate in a water-in-glass evacuated tube solar water heater," Solar Energy, vol. 78, no. 2, pp. 257-267, 2005.

[16] G. L. Morrison, I. Budihardjo, and M. Behnia, "Water-in-glass evacuated tube solar water heaters," Solar Energy, vol. 76, no. 13, pp. 135-140, 2004.
[17] A. Hobbi and K. Siddiqui, "Optimal design of a forced circulation solar water heating system for a residential unit in cold climate using TRNSYS," Solar Energy, vol. 83, no. 5, pp. 700-714, 2009.

[18] M. S. Seveda, "Performance analysis of solar water heater in $\mathrm{NEH}$ region of India," International Journal of Renewable and Sustainable Energy, vol. 2, no. 3, pp. 93-98, 2013.

[19] Y. Yang, Q. Wang, D. Xiu, Z. Zhao, and Q. Sun, "A building integrated solar collector: all-ceramic solar collector," Energy and Buildings, vol. 62, pp. 15-17, 2013.

[20] M. Souliotis, D. Chemisana, Y. G. Caouris, and Y. Tripanagnostopoulos, "Experimental study of integrated collector storage solar water heaters," Renewable Energy, vol. 50, pp. 1083-1094, 2013.

[21] C. C. Chien, C. K. Kung, C. C. Chang, W. S. Lee, C. S. Jwo, and S. L. Chen, "Theoretical and experimental investigations of a twophase thermosyphon solar water heater," Energy, vol. 36, no. 1, pp. 415-423, 2011.

[22] K. S. Ong, "A finite-difference method to evaluate the thermal performance of a solar water heater," Solar Energy, vol. 16, no. 3-4, pp. 137-147, 1974.

[23] K. S. Ong, "Experimental comparative performance testing of solar water heaters," International Journal of Low-Carbon Technologies, vol. 6, no. 4, Article ID ctr014, pp. 270-276, 2011.

[24] G. N. Tiwari, S. N. Shukla, and M. S. Sodha, "Performance of large solar water heating system: thermosyphon mode," Energy Conversion \& Management, vol. 25, no. 1, pp. 29-38, 1985.

[25] B. Perers and C. Bales, "A solar collector model for TRNSYS simulation and system testing," IEA SHC Report, 2002.

[26] L. M. Ayompe, A. Duffy, S. J. McCormack, and M. Conlon, "Validated TRNSYS model for forced circulation solar water heating systems with flat plate and heat pipe evacuated tube collectors," Applied Thermal Engineering, vol. 31, no. 8-9, pp. 1536-1542, 2011.

[27] V. Bădescu, "The dependence of solar air heater performance upon tilt and orientation," Energy Conversion and Management, vol. 30, no. 2, pp. 179-185, 1990.

[28] J. D. Felske, "The effect of off-south orientation on the performance of flat-plate solar collectors," Solar Energy, vol. 20, no. 1, pp. 29-36, 1978.

[29] V. H. Morcos, "Optimum tilt angle and orientation for solar collectors in Assiut, Egypt," Renewable Energy, vol. 4, no. 3, pp. 291298, 1994. 

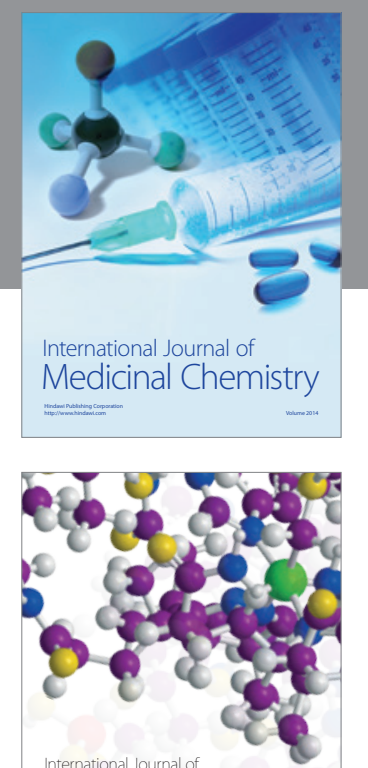

\section{Carbohydrate} Chemistry

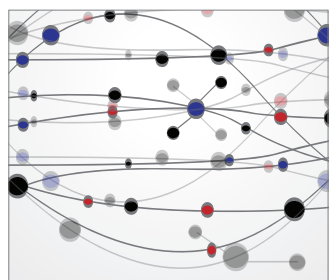

The Scientific World Journal
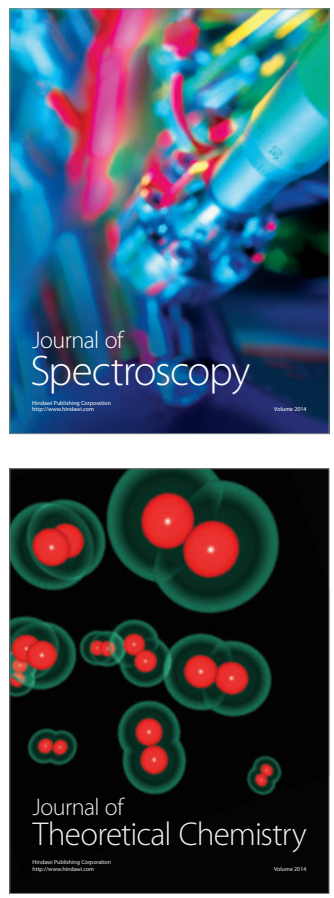
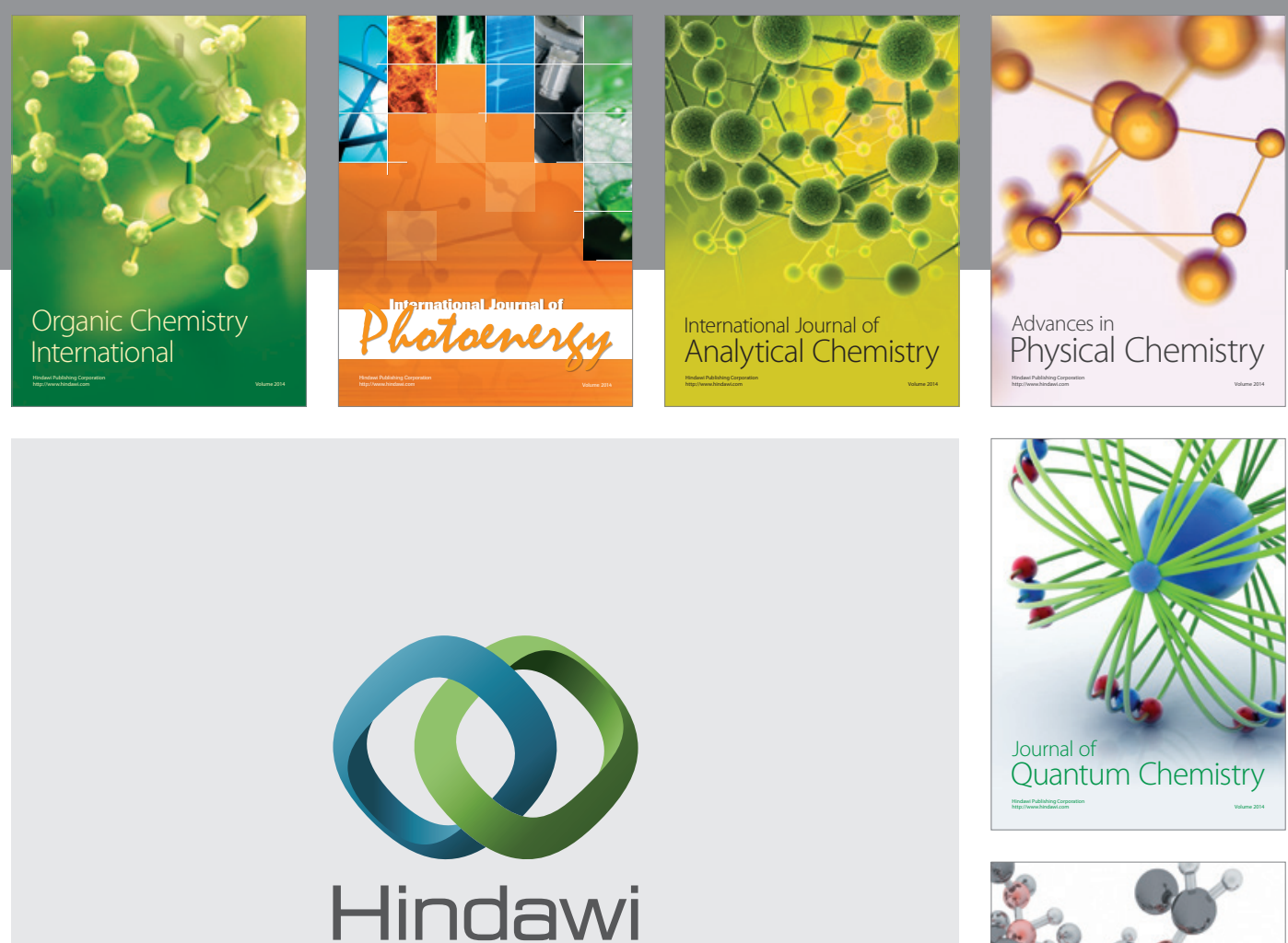

Submit your manuscripts at

http://www.hindawi.com

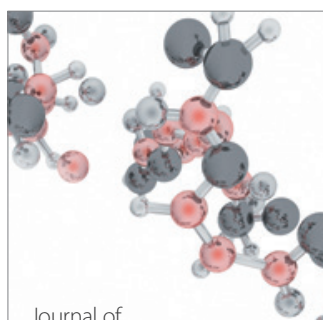

Analytical Methods

in Chemistry

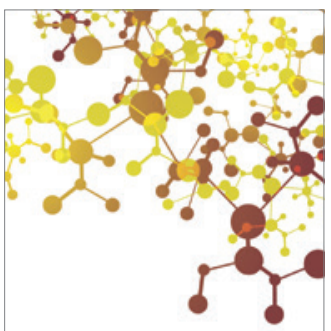

Journal of

Applied Chemistry

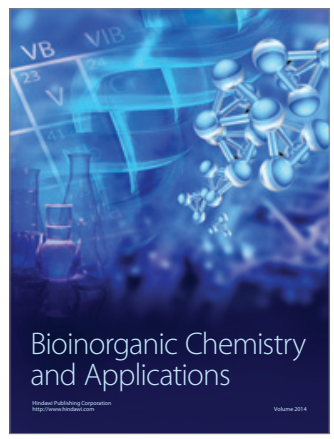

Inorganic Chemistry
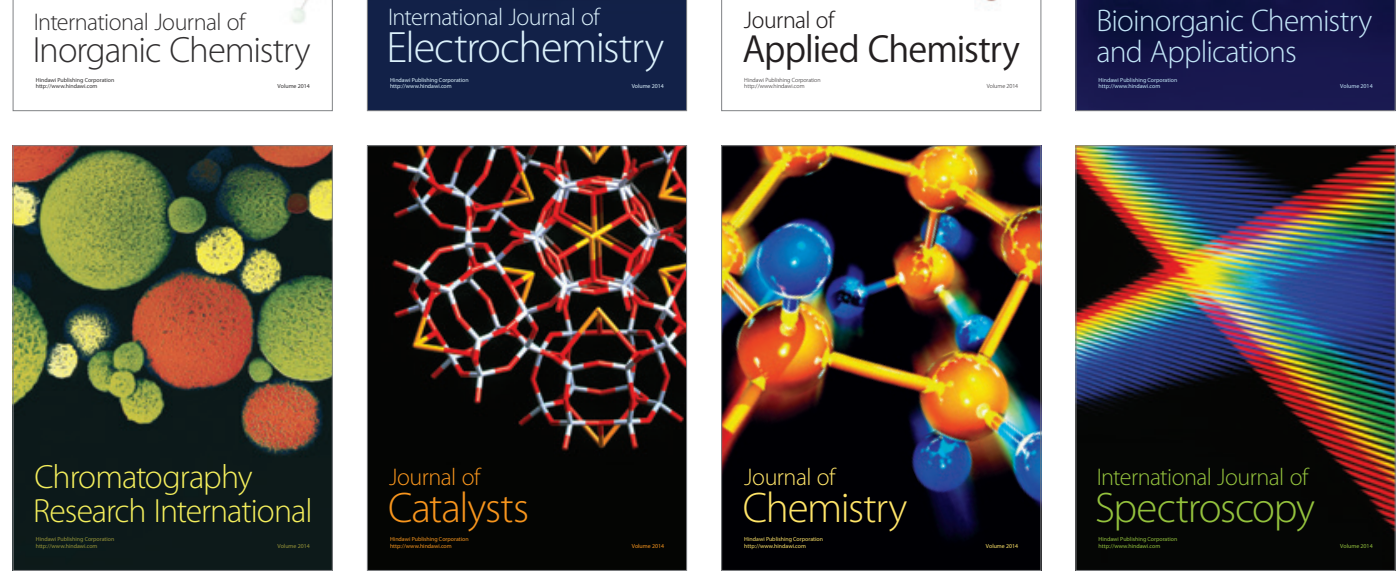